\title{
The attempted trial of Boniface VIII for heresy ${ }^{1}$
}

\author{
Jeffrey Denton
}

Despite strenuous efforts by the French Crown and its allies over a period of eight years Boniface VIII was not ultimately tried. Legal procedures for a trial were put in motion in 1303, in an attempt to summon the pope before a General Council of the Church; and later, after his death in October 1303, as the accusations continued to grow, there was a protracted quest to persuade the new French pope, Clement V, to condemn Boniface posthumously. Over the period 1303 to 1311 the accusations against the pope developed and became more elaborate until the legal processes, first against the person of the pope and then against his memory, were abandoned following a political agreement. The posthumous stages of the whole affair were soon very largely forgotten, indeed became shrouded in secrecy as an embarrassing episode in both papal and French history, ${ }^{2}$ but the conflict during the last stages of Boniface's life, beginning in 1301 and culminating in the attempts to bring him to trial in 1303, produced masses of documentation and political treatises $^{3}$ that were of continuing significance for the French monarchy and the French state and, indeed, for the future of the papacy. It was the first time in European history that such a welter of detailed evidence was produced by an attempt to defame or indict a supreme political leader. The surviving evidence is not always easy to interpret and has at times been wildly misinterpreted. This chapter will concentrate on the evidence of 1303: specifically, the sets of complaints against the pope of March and June 1303 which constituted the first stages in the planned legal process and from which the later accusations very largely stemmed.

What were the charges contained in the initial trial texts of March and June 1303? We now have the benefit of Jean Coste's excellent critical editions of all the complaints against Boniface. ${ }^{4}$ The March text ${ }^{5}$ was a set of carefully prepared propositions by the knight and lawyer William de Nogaret, presented to Philip IV and his council. It constituted a trenchant defence of the Church, beginning, like a sermon, with the claim that events foreseen by St Peter, 
'glorious prince of apostle', had come to pass: 'But there were false prophets also among the people, even as there shall be false teachers among you' "by reason of whom the way of truth shall be evil spoken of. And through covetousness shall they with feigned words make merchandise of you' 'following the way of Balaam the son of Bosor who loved the ways of unrighteousness .... ${ }^{6}$ The first specific charge, providing the main thrust of the whole declaration, was that Boniface was a false pope and usurper of the apostolic see: he was a master of untruths, claiming to be called 'Bonifacius' when he was in every way 'maleficus', entering 'not by the door into the sheepfold' but rather as 'a thief and a robber', 7 deceiving his predecessor, Celestine V, into resigning (in December 1294), laying violent hands upon him and appropriating to himself the Church of Rome. He had been tolerated, for fear of schism, until it could be seen by his fruits ${ }^{8}$ whether he had achieved office through the working of the Holy Spirit; now it was clear to all that his fruits were the most noxious. The evil tree 'should be hewn down and cast into the fire'. ${ }^{9}$ The central charge, therefore, was that Boniface had no rightful claim to be pope.

The other specific accusations in March were very succinctly stated: that the pope was a manifest heretic; that he was the worst simoniac that the world had ever known; and that his crimes were so great and so manifest that they could no longer be tolerated without subversion of the Church. Some of these manifest crimes were listed: for example, instead of nurturing churches he tore them apart, wickedly squandering the goods of the poor, supporting evil men and taking vengeance on the just, and imposing grievous burdens on the people of God and the leaders of the people. There was, thus, no pulling of punches in Nogaret's declaration; but, at the same time, the accusations were broad rather than precise. With his biblical, indeed theological, approach, ${ }^{10}$ Nogaret had certainly established a distinctive and newly relevant case against the pope. His claim was that it had become clear from his actions as pope that he was an impostor and that he had no God-given authority. Although the March statement is a keen and innovative assault upon the pope, in continuing to emphasise Boniface's supposedly illegitimate elevation it was in some ways backward-looking. It was strongly reminiscent, no doubt consciously so, of the charges made against the pope six years earlier by the disaffected cardinals, James and Peter Colonna. ${ }^{11}$

As an appeal to Philip IV to set in motion the convocation of a General Council the March statement was ineffective. No firm decisions were taken. Reasons for delay are suggested by the fact that there was soon a clear change of tactics. By June not only had the list of charges grown extensively but also the emphasis had shifted radically. ${ }^{12}$ The old accusations were not abandoned, but the theme now was Boniface the heretic rather than Boniface the usurper. This broke new ground, moving further away from the earlier Colonna charges, though probably influenced by recent information derived in part from Peter Colonna. ${ }^{13}$ 
Indeed, the June gathering was itself of a distinctly different kind from the earlier meeting of the king's council. In March, for instance, two archbishops and three bishops had been present; now there were five archbishops and twenty-one bishops. Proceedings in June moved successfully to statements of adherence to the process of summoning a Council - statements first by the king and then, with some conditions attached, by the assembled prelates. At this new assembly it was Nogaret's junior accomplice, William de Plaisians, who presented the case against Boniface; and he took an oath to pursue the matter before the planned Council. All the new accusations, twenty-eight of them, were summed up by the initial denunciation that the pope was a thoroughgoing heretic: 'hereticus perfectus'. This charge of heresy had come very largely out of the blue in $1303 ;{ }^{14}$ and it was at the June assembly that some circumstantial support for the charge was, for the first time, made public and set down in writing. The accusations were now, though certainly not substantiated, at least bolstered with some detail.

In brief the allegations supporting the charge of heresy were as follows. The pope denied the immortality of the soul, transubstantiation, the existence of an afterlife and the efficacy of penance, and he approved of a heretical work by Arnold of Villanova. In addition to these charges which can be associated directly with a common perception, then as now, of heresy, he was accused of fornication, of sodomy, of homicide, of encouraging idolatry by having images of himself erected in churches, of engaging in demonolatry and black magic, of committing simoniacal practices in the trading of ecclesiastical offices, of causing the death of Celestine V, of undermining the college of cardinals and the monastic and mendicant orders, of planning the destruction of the French king and the French people, of being responsible for the loss of the Holy Land, of oppressing Christians and working as an enemy of peace for the perdition of souls and for the destruction of the Church and of the faith. With this outright defamation of Boniface the future pattern of the attacks on the pope was fully established. It was an exposure of his scandalous behaviour as pope and of his scandalous personal morality. In the years that followed there would be further elaborations on these themes. But of special importance, and there can be no doubt about this, was the charge of heresy. Heresy was now the core of the matter.

There has been a tendency to take these accusations at face value, and to believe that they can be individually investigated in order to arrive at a true understanding of the pope's behaviour and attitudes. Although Jean Coste in his recent work adopted a rigorously critical approach to all the evidence, the central intention of his analysis was to discover whether or not the pope was innocent of the charges levelled against him; his meticulously worked out conclusion was, rather predictably, that the precise charges cannot be substantiated, but that the character and behaviour of this pontiff 'sans scrupules' left much to be desired. ${ }^{15}$ It is as though the sheer enormity of the accusations continues to make it difficult to see behind them and to set them in context. 
The first most important question is not how true the individual charges were, but rather whether they actually represented the reasons for the Francopapal rift and for the attempt to bring Boniface to trial. Clearly, if we are to understand what kinds of reality lie behind the documents of 1303, we need to construct a secure legal and political context for them. And the startingpoint must be the nature of the documents themselves. What were they?

Both documents were notarially attested statements aiming to establish a proper juridical procedure. They are legal documents, in the nature of individual appeals, in March by William de Nogaret and in June by William de Plaisians. These secular lawyers were the key royal agents in the whole affair. Nogaret's statement was, in the first place, a supplication to the king that, having interceded with leading churchmen and laymen, especially the cardinals and prelates, and with the people, he should convoke a General Council, at which this 'most evil' pope would be condemned and the cardinals would provide a new pastor for the Church. It was abundantly clear from the terms in which this procedure was set out that there was no doubt about the intended outcome of the planned trial. Nogaret's statement comprised, in the second place, a supplication that the king and the cardinals should place the pope in custody and appoint a vicar to administer the Church until a new pontiff could be provided, thus avoiding all possibility of a schism and preventing the 'infamous' Boniface from impeding the proceedings.

Plaisians, in June, presented a more developed set of appeals. He appealed at length to the king and to the French prelates, with elaborate statements that he was acting for the good of the Church and the faith. The result was that the king, having given his own formal support, himself appealed to all the prelates who were present to work for a General Council and issued a 'precautionary' appeal against any action that the pope might take. The prelates then formally consented to the summoning of a Council, with the proviso that they were unwilling to be a party in a legal case, and they too issued a 'precautionary' appeal against any papal action.

Thus by a process of appeals was legal procedure initiated. These were not standard ecclesiastical appeals of a common kind, appeals, that is, from one jurisdiction to a higher jurisdiction; even so, these individual petitions of mere laymen were bolstered by royal and ecclesiastical corroboration and endorsement. The French lawyers were carefully presenting their case within the Romano-canonical tradition, which was marked by ample possibilities of supplication. The particular kind of provocationes (the 'precautionary' appeals) which completed the initial procedures were entreaties against future harm, and these had come to be employed, not infrequently, in the late thirteenth century in cases with political overtones. ${ }^{16}$

The accusations against the pope were, thus, elements within a jurisprudential framework. They should not be read as though they were elements of a political pamphlet or as though they formed part of some coherent statement of policy or belief. Did the French lawyers, then, have specific juristic 
precedents to follow in setting out to achieve the deposition of the pope? The advancement of the papal monarchy in the thirteenth century and the prevailing belief in the superiority of the pope's overarching spiritual power ${ }^{17}$ were such that it is difficult to see the assault upon Boniface as anything other than extraordinary. It was, after all, a fundamental principle of canon law that the pope could be judged by no man, a claim supported on occasion by a text of St Paul: 'But he that is spiritual judgeth all things, yet he himself is judged of no man. ${ }^{, 18}$ And it is certainly true that the French lawyers were treading new ground in actually setting in motion the summoning of a General Council to try the supreme pontiff. Nowhere had precise legal processes for the trial of a pope been formulated. Yet, in the world of Realpolitik (and schisms) the position of popes (not only anti-popes) had often been challenged and threatened, and Gratian's Decretum (c. 1140), the sourcebook par excellence of papal superiority, had itself cited cases of popes who had submitted to judgments. More than this, it is clear that in the commentaries of canonists, from $c .1140$ onwards, the possibility of papal deposition was both acknowledged and discussed. ${ }^{19}$ While this canonistic debate apparently receded for much of the thirteenth century, there can be no doubt that $c .1300$ legal principles relating to papal deposition were well known within - and probably also without - ecclesiastical circles. And it should be stressed that the heated question of the resignation of Celestine $\mathrm{V}$ had certainly brought to the fore the whole issue of papal suitability.

It seems, in fact, very likely that in the formulation of the appeals of 1303, especially of June 1303, the French lawyers took their lead from the canonists, and especially from the decretists, the commentators on Gratian's Decretum, working from $c .1140$ to $c$. 1220 . The text which had demanded elucidation was Gratian's declaration that the pope could be judged by no man 'unless he is shown to have deviated from the faith (nisi deprehendatur a fide devius) ${ }^{20}$ - unless, that is, he is considered to be a heretic. Glosses upon this 'dictum', notably those of Huguccio and Teutonicus, ${ }^{21}$ could well have been an inspiration, perhaps a direct inspiration, in the shaping of the 1303 appeals. Above all else, there was, of course, the emphasis upon heresy. For the canonists a charge of heresy just had to be the crux of the matter. In addition, the canonists stressed that there should be a common belief in the validity of the charge of heresy; and it is a constant refrain in June 1303, in accusation after accusation, that the pope was 'publicly defamed'. Although there was no consistent canonical theory on what, in the context of a papal condemnation, should or should not constitute heresy, Huguccio had unambiguously claimed that a pope could be condemned of notorious crimes, since to scandalise the Church, by committing, for example, simony or fornication, was itself a heresy; and in 1303 the many accusations of scandalous behaviour and scandalous personal morality were undoubtedly part of the overall charge of heresy. Also, the importance of persistent contumacy had been stressed by the canonists; and the 1303 appeals, in the ninth year of the pontificate, having moved 
decisively away from debate on the legality or otherwise of the pope's elevation, derived much of their force from the claim of long-term and continuing misdemeanours.

Furthermore, it is likely that the canonical influence upon the French lawyers was immediate and contemporary. The work of the decretists was being studied anew by canonists active in the late thirteenth and early fourteenth centuries, whether by those critical of the papal monarchy (notably John Monachus and William Durand the Younger) or by those with the highest regard for papal authority (notably the outstanding academic jurists Guy de Baysio and his pupil John Andreae). It is clear that there was a renewed interest in the question of popes who 'deviated from the faith'. ${ }^{22}$ Both Guy de Baysio and John Andreae took the view that resistance to a pope suspected of heresy required a criminal indictment and a subsequent trial, and Guy stated firmly the opinion that a General Council alone was competent to judge a pope. So, it is even possible that some of the inspiration for the shaping of the assault upon Boniface VIII came from the innermost ranks of his own learned supporters.

It is, therefore, first and foremost, within a legal context that the form and content of the 1303 appeals must be understood and judged. But not only in a legal context. The attack upon Boniface VIII by the French king and court was, there is no question, a political attack, concerning the nature and the exercise of papal authority in relation to royal authority. The very accusation of heresy was, of course, charged with deep political significance. It was, after all, more appropriate that the pope should be a saint. The heresy charge was an echo of imperial accusations against Gregory VII in the late eleventh century. ${ }^{23}$ And it is surely significant that, in the thirteenth century, it was the slur of heresy that had become a basic justification for papal actions against emperors. $^{24}$

Although heresy was the antithesis of sanctity, the two had developed a symbiotic affinity. ${ }^{25}$ In some ways they were understandable, almost even definable, only because of each other; and during the thirteenth century the papacy had drawn to itself ultimate and exclusive responsibility for identifying both heretics and saints. There emerged, for the one, earnest inquisitorial procedures and, for the other, more and more elaborate and protracted canonisation enquiries. Intense political influences pervaded both processes. While papal control was dominant, in many cases relating to both heresy and sanctity the ascendant authority of the French monarchy had been at stake. Indeed, since the time of the Albigensian crusade early in the century opposition to heresy had become a key feature of the work of the Capetian dynasty; and in 1297, at the beginning of a four-and-a-half-year period of alliance between Boniface and Philip IV, the pope had, with all due ceremony, canonised the king's grandfather Louis IX, one of whose virtues had been that he had taken up arms against the enemies of Christendom, including heretics. ${ }^{26}$ Thus, it is clear that the attack upon Boniface as a heretic was a dramatic way, at a time 
of bitter crisis with the papacy, of reinforcing the saintly image of the Capetian lineage. And in this climate of polarised and politicised vices and virtues, it comes as no surprise that, after Boniface VIII's death, Philip pressed - and with success - for the canonisation (in 1313) of Celestine V, the hermit pope whose controversial resignation had made way for Boniface's elevation. Boniface's enemies had heresy-hunters and saints among their ranks.

It is striking, too, that this was an age in which major political developments or wrangles might well result in high-profile legal actions. It was an age, in other words, of political trials and attempted political trials, which often displayed a large element of propaganda or political manoeuvring and must thus rank as show trials. Some of these trials, involving spectacular accusations, were (and remain) notorious: for instance, the processes against the Knights Templar between 1307 and 1314 and against Guichard, bishop of Troyes, between 1308 and 1313. ${ }^{27}$ Others are less well known. For example, following a rising of the commune of Laon in February 1295 and an assault upon the cathedral church, Boniface VIII had attempted to settle the dispute by initiating legal proceedings against the citizens of Laon, in support of the sentences of excommunication and interdict of local churchmen; in the event, it was only by royal intervention that, in 1298, the church and citizens of Laon became reconciled. ${ }^{28}$ Another legal intervention by the pope, this time in England, had also been a dismal failure. Boniface had responded to a plea by John Ferrers, concerning what in fact had been the Crown's expropriation of his father's earldom of Derby, by appointing Robert Winchelsey, archbishop of Canterbury, as papal judge delegate to hear a case against Thomas of Lancaster on the grounds of usury. ${ }^{29}$ Proceedings began in St Paul's London between April and June 1301. Since the action turned on contractual arrangements about the fief of an earldom and called into question royal policy relating to the creation of Lancastrian wealth, no one can have been surprised when this extraordinary legal process was suddenly aborted, with the archbishop's commissaries declaring that they did not dare to continue.

Two other legal assaults had been directed at individual bishops, one English and the other French. These cases against churchmen, initiated by laymen, were interesting precursors of the case against the bishop of Rome. The intriguing attack upon Walter Langton, bishop of Coventry and Lichfield and king's treasurer, made by the knight John Lovetot junior, had led to the bishop's suspension and summons to Rome. ${ }^{30}$ He cleared his name in 1303. The accusations against the bishop were in many respects similar to those against Boniface, though without any specific mention of heresy: there was the claim of public defamation (vox fama et publica) and the mixture of irresponsible ecclesiastical policies (simony and pluralism) with immoral and criminal behaviour (adultery and murder) and consorting with the devil.

The second recent case against a bishop patently foreshadowed the accusations against the pope. Indeed, it was the renowned attack by Philip of France upon Bernard Saisset, bishop of Pamiers, that brought down the full 
force of papal wrath against the French Crown and precipitated the bitter crisis between king and pope. ${ }^{31}$ The Saisset case was 'the first important treason trial of a cleric in later medieval France'. ${ }^{32}$ The bishop was seized, held prisoner and tried before the king and council (in October 1301), before being sent to Rome early the following year. ${ }^{33}$ The political relationship beween the case against Saisset and the case against Boniface has been frequently acknowledged and yet merits closer study. It must suffice here to point to the nature of the accusations against Saisset: he was accused not only of notoriously scandalous remarks against the king, kingdom, and royal court, and of conspiring time and again against the king, with the count of Foix, the count of Comminges and the king of England, but also of manifest simony, of claiming that fornication with men in holy orders was not a sin and that Pope Boniface was the devil incarnate, and of spreading many heresies, notably in opposition to the sacrament of penitence. ${ }^{34}$

The emergence of the open and personal anti-papal censures in 1303 must thus be seen against a backdrop of high-level, and judicial, lay/clerical tensions. And there is another political context to be considered. The accusations served an immediate and vital political purpose: the marshalling of public opinion. Directly indicative of this aim was the repetition time and again in the June complaints that the pope's scandalous behaviour was well-known: 'on this matter public opinion is working against him (super hoc laborat publica fama contra ipsum)', or 'on these matters he is publicly defamed (super hec est publice diffamatus)', or 'on this matter there is public outcry (de hoc est publica vox et fama)'. ${ }^{35}$ In truth, whatever the situation before March and June 1303, the public revelations of the pope's scandalous transgressions were themselves designed to ensure that his vices were notorious. No claims could have been more self-fulfilling. The planned summoning of a General Council at which the pope's trial could take place required widespread support, and the public accusations were the first stage in an elaborate policy of obtaining that support. Within days of the June assembly remarkable procedures were initiated for obtaining dossiers of letters of adherence to the summoning of a Council from nobility, clergy and townspeople throughout the realm. ${ }^{36}$ The controlling of public opinion was part of the political, and legal, process. A mere spat between Philip and Boniface would not unseat the pope.

The denunciations need to be seen, therefore, in the context of an appeal to the whole French Church, its lay as well as its clerical members. For this purpose accusations that were very precise and in some way substantiated were unnecessary. Dramatic and general accusations that were difficult to contradict were the order of the day. There was certainly no point in opening up debatable political matters. The censures must serve to carry the Crown's case forward. It was therefore important that the agenda for the planned legal proceedings be at least indicated. In both March and June the appealers declared that the details concerning heresy would be specified in due course in the proper place and at the proper time. 
What, then, should we deduce from this survey of the legal and political context of the trial texts of 1303? It is tempting to believe that the carefully formulated charges were the outright inventions of the calculating French lawyers. But this is too simple a conclusion. To carry weight the accusations had to be credible, and there were certainly commonly held views of the kinds of reprehensible behaviour of which churchmen, especially those enmeshed in the political world, were capable. It seems clear that the accusations, however much they were being turned to the advantage of the French Crown, were derived, even at the outset, from common perceptions and from stories with at least some degree of general acceptance. Take, for example, the accusation of homicide. There is evidence which suggests how this charge may have emerged. It can be related to a specific incident. This was the death of fifty or so pilgrims crushed under foot by a great crowd on the occasion of the pope's Jubilee celebrations in $1300 .{ }^{37}$ Also, there were cases, it was claimed, of clerks having died after being gaoled at the pope's orders, in some instances as a result of disputing among themselves Celestine V's right of resignation. That clerks had died as an indirect result of papal actions, and perhaps even papal orders, could easily have given rise to the belief that the pope was guilty of homicide, and it is possible that this was quite a widely disseminated story rather than a deliberate and coldly calculating fabrication.

Some truths may be detectable in the charges. Yet, it is certain that there is little or no point in attempting, item by item, to substantiate or deny the scurrilous anti-papal imputations. Their very forcefulness, tied as they were to a political campaign, was derived from the fact that they were not readily open to debate. Neither the real Boniface nor the real ecclesiastical and political world in which he moved can be effectively revealed through an investigation of the claims made in the 1303 trial texts. In respect of the crucial heresy charge, it is fruitless to attempt to find identifiable and specific heretical traits in Boniface's beliefs and behaviour. The accusations of denying the immortality of the soul and the existence of an afterlife have been linked, notably in an article by Wenck almost a century ago, ${ }^{38}$ to the heterodox Aristotelianism and materialism of the late thirteenth century. Thus, the possibility that the pope belonged to a new heretical sect was opened up. But here is a profound irony. The papal policies which had given rise to intense animosity in the French court were a defence of the supremacy of the priesthood, which, evidenced especially in the pope's declaration Unam Sanctam, can be seen, altogether plausibly, as a reaction to the newly threatening Aristotelian notions of the discrete validity of temporal rule. ${ }^{39}$ Were the pope's accusers aware - amusedly aware perhaps - of the paradox inherent in their accusations? Their 'heretic' was the staunchest of defenders of priestly authority. There is much to indicate that he was, in addition, careless in word and vainglorious in deed. But to argue that he belonged to some kind of heretical sect seems nothing short of ludicrous. A pointer to what the heresy charge truly signified to contemporaries may well lie in a statement by Peter Dubois. ${ }^{40}$ 
Dubois was a commentator close to the royal court. He wrote a rejoinder to Boniface's bull 'Ausculta fili' of late 1301, with its famous statement that the king was subject to the pope in both spiritual and temporal matters and its conclusion that the pope considered anyone believing otherwise to be a heretic. Dubois responded that a pope capable of making such a claim should himself be considered a heretic. This suggests that for Dubois, and probably many others in France, the charge of heresy was a charge of abject failure in the defence of the Church and thus of the faith.

The details of the portentous Franco-papal rift of 1301 to 1303 have engaged the attention of generations of historians. Yet the reasons for the crisis have aroused little discussion or debate. The main explanation for this is that one seductive interpretation has long held sway. There is a general consensus that this was a clash between a newly emerging secular and national monarchy and a papacy defending the traditional pretensions of the universal Church. This dichotomy between the new and the traditional demands scrutiny. After all, the French monarchy had its own traditional rights over its own Church and, far from having purely secular concerns, claimed repeatedly to be supporting the interests of the universal Church. It is a surprising fact that the political issues at stake in this Franco-papal conflict have yet to be adequately clarified. But our analysis of the charges which emanated from the French court in 1303 demonstrates that the actual lists of accusations are altogether inadequate sources for the study of the reasons for the attack upon the pope. Perhaps it is artless to expect that trial texts concerning those in high - not to say the highest - office might themselves indicate the underlying reasons for the intended trial. Indictments, indeed, may well have a political context which legal documentation serves to hide rather than elucidate. The political issues underpinning the Franco-papal clash must be sought in other sources. Of special interest for a comprehension of the immediate circumstances surrounding the decision to plan for a papal trial are the twelve articles sent by Boniface in late 1302 and the king's twelve responses of February $1303 .{ }^{41}$ Here was a dialogue about some major issues, as, for example, the filling of vacant ecclesiastical benefices. Here are some indications of the political causes of bitterness and tension. The French accusations of March and June 1303 need, certainly, to be studied in relation to their own legal and political context, but, in the quest for an understanding of the reasons for the attempted papal indictment, these trial texts are a false trail.

\section{Notes}

1 The author gratefully acknowledges that the initial research from which this article has developed was undertaken during his tenure of a British Academy Readership.

2 See T. Schmidt, Der Bonifaz-Prozess: Verfahren der Papstanklage in der Zeit Bonifaz' VIII und Clemens' $V$ (Forschungen zur kirchlichen Rechtsgeschichte und zum Kirchenrecht, 19, Cologne and Vienna, 1989), pp. 435-6, and for the continued shadowy existence of the Boniface affair in French historiography, p. 2 n.9. 
3 See especially P. Dupuy, Histoire du differend d'entre le pape Boniface VIII et Philippes le Bel (Paris, 1665); R. Scholz, Die Publizistik zur Zeit Philipps des Schönen und Bonifaz' VIII (Stuttgart, 1903); J. Rivière, Le Problème de l'église et de l'état au temps de Philippe le Bel (Louvain and Paris, 1926).

4 J. Coste (ed.) Boniface VIII en procès: articles d'accusation et dépositions des témoins (Pubblicazioni della Fondazione Camillo Caetani, Studi e Documenti d'Archivio, 5, Rome, 1995).

5 Ibid., pp. 103-22.

6 II Peter 2, 1-3, 15. Biblical texts are cited here from the Authorized Version.

7 John $10,1$.

8 See Matthew 7, 15-20.

9 Matthew 3, 10.

10 Schmidt, Bonifaz-Prozess, pp. 60-1.

11 For the Colonna manifestos see Coste (ed.), Boniface en procès, pp. 32-63.

12 Ibid., pp. 122-73.

13 Ibid., pp. 128-31.

14 Ibid., pp. 90-103.

15 See especially ibid., pp. 885-908.

16 N. Adams and C. Donahue (eds), Select Cases from the Ecclesiastical Courts of the Province of Canterbury c. 1200-1301, Selden Society, 95, 1978-9, introduction, p. 62 and n. 6, and J. H. Denton, 'Philip the Fair and the ecclesiastical assemblies of 1294-1295', Transactions of the American Philosophical Society, 81 pt 1 (1991), 17 and n. 51.

17 See, for example, J. A. Watt, The Theory of Papal Monarchy in the Thirteenth Century (London, 1965).

18 I Corinthians 2, 15. See John of Paris, On Royal Power, (ed.) J. A. Watt (Toronto, 1971), p. 31.

19 B. Tierney, Foundations of the Conciliar Theory (Cambridge, 1955, reprinted 1968), pp. 57-67; J. M. Moynihan, Papal Immunity and Liability in the Writings of the Medieval Canonists (Analecta Gregoriana, 120, Rome, 1961), pp. 43-106; E. Peters, The Shadow King (New Haven and London, 1970), pp. 220-2; and Schmidt, Bonifaz-Prozess, 1, 62.

20 D.40 c. 6 - see E. Friedberg (ed.) Corpus iuris canonici (Leipzig, 1922), I, p. 146. For the origins of this 'dictum' see Moynihan, Papal Immunity, pp. 27-42.

21 Tierney, Foundations, pp. 58-67, 248-50, and Moynihan, Papal Immunity, pp. 75-106.

22 Tierney, Foundations, pp. 179-96, 212-15, and Moynihan, Papal Immunity, pp. 117-19.

23 M. Chazan, L'Empire et l'histoire universelle de Sigebert de Gembloux à Jean de SaintVictor (XII $-X I V^{e}$ siècle) (Paris, 1999), pp. 273-5.

24 Ibid., pp. 575-7.

25 For this paragraph see J. H. Denton, 'Heresy and sanctity at the time of Boniface VIII', to be published in Tolerance and Repression in the Middle Ages (1998 Conference Papers, Institute of Byzantine Research, Athens).

26 See especially A. Vauchez, La Sainteté en occident aux derniers siècles du moyen âge, École française de Rome, 1988, pp. 74n, 214, 265, 415-17, and J. H. Denton, 'Taxation and the conflict between Philip the Fair and Boniface VIII', French History, 11 (1997), 249-53. 
27 See inter alia M. Barber, The Trial of the Templars (Cambridge, 1978), and A. Rigault, Le Procès de Guichard, évêque de Troyes (Paris, 1896).

28 J. Denton, 'The second uprising at Laon and its aftermath, 1295-98', Bulletin of the John Rylands University Library of Manchester, 72: 3 (1990), 79-92.

29 M. Bateson and J. Denton, 'Usury and comital disinheritance. The case of Ferrers versus Lancaster, St Paul's, London 1301', Journal of Ecclesiastical History, 43 (1992), 60-96.

30 For the accusations against him see T. Rymer (ed.), Foedera: conventiones, litterae et cujuscunque generis acta publica (4 vols in 7, London, 1816-1869), I ii, pp. 956-7. Other primary and secondary sources are cited in J. B. Hughes (ed.) The Register of Walter Langton, Bishop of Coventry and Lichfield 1296-1321 (Canterbury and York Society, 2001), I, p. xxxv, and J. H. Denton, Robert Winchelsey and the Crown 12941313 (Cambridge, 1980), p. 53 (the statement here of 'intercourse' with the devil meant, of course, communication with the devil: cf Hughes, (ed.), Register of Langton, p. $\operatorname{xxxv}$ n.115).

31 For the Saisset affair see especially Dupuy, Histoire du differend, pp. 621-62; D. de Sainte-Marthe et al. (eds), Gallia Christiana in provincias ecclesiasticas distributa (16 vols, Paris, 1715-1865), XIII, instrumenta 107-38; and J.-M.Vidal, Bernard Saisset (Toulouse and Paris, 1926), pp. 76-115.

32 S. H. Cuttler, The Law of Treason and Treason Trials in Later Medieval France (Cambridge, 1981), p. 73.

33 G. Digard, Philippe le Bel et le Saint-Siège de 1285 à 1304 (2 vols, Paris, 1936), II, pp. 95-6.

34 Dupuy, Histoire du differend, pp. 628, 653-6, and Saint-Marthe et al (eds), Gallia Christiana, XIII, instrumenta 110, 116-18.

35 Coste (ed.), Boniface en procès, pp. 145, 149-50, 152, 155, 159, 161, 163.

36 See W. J. Courtenay, 'Between pope and king: the Parisian letters of adhesion of 1303', Speculum, 71 (1996), 577-605, and S. Menache, 'A propaganda campaign in the reign of Philip the Fair 1302-1303', French History, 4 (1990), 427-54.

37 Coste (ed.), Boniface en procès, p. 302 n.1.

38 K. Wenck, 'War Bonifaz VIII ein Ketzer?', Historische Zeitschrift, 94 (1905), 1-66. See Coste (ed.), Boniface en procès, pp. 905-6.

39 W. Ullmann, 'Boniface VIII and his contemporary scholarship', Journal of Theological Studies, 27 (1976), 58-87.

40 Coste (ed.), Boniface en procès, p. 92.

41 Dupuy, Histoire du differend, pp. 90-5; C. Port (ed.)., Livre de Guillaume le Maire (Documents inédits de France, Mélanges historiques, vol. 2, 1877), pp. 380-4; and Digard, Philippe le Bel et le Saint-Siège, II, pp. 138-45. 